\title{
Classification and Dramatic Epidemic of Diabetes Mellitus in Kinshasa Hinterland: The Prominent Role of Type 2 Diabetes and Lifestyle Changes among Africans
}

\author{
Kasiam Lasi On'Kin J B*, Longo-Mbenza $B^{*}$, Nge Okwe $A^{* *}$, Kangola Kabangu $\mathrm{N}^{\star *}$, Mbungu Fuele $\mathrm{S}^{* *}$, \\ Milongo Dipa $G^{* *}$ \\ ${ }^{*}$ Department of Internal Medicine, University of Kinshasa, DRC \\ ** Biostatistics Unit, LOMO MEDICAL Center and Heart of Africa Center of Cardiology, Kinshasa, DRC
}

\begin{abstract}
Background: Classification of diabetes mellitus is not easily stated in Central Africa using the current diabetes classification of World Health Organization/American Diabetes Association. The objective of the study is to determine the prevalence, classification and risk factors of diabetes mellitus in Kinshasa Hinterland.

Methods: A Multilevel and stratified random sample cross-sectional study included 9770 black Africans (4580 men and 5190 women) aged 12 years and above in urban metropolitan (Kinshasa city) and rural (Kikwit) areas. Participants were examined and administered a structured questionnaire and a capillary whole blood glucose test was done.
\end{abstract}

Results: The mean age of participants was $46 \pm 15$ years. Overall crude and age adjusted prevalences of diabetes were $25 \% \quad(n=2472)$ and $18 \%$, respectively. Using WHO/ADA classification, Type diabetes (80\%) was commoner than undetermined form (12\%), Type $1 B$ (3.5\%), Type $1 A(2.5 \%)$ and Other specific types (2\%). According to plasma insulin and plasma C-peptide levels, participants with undetermined form were classified Type 2 diabetics. Thus, the rate of Type 2 diabetes among diabetics was estimated $92 \%$. Urban location, age, abdominal obesity, arterial hypertension, physical inactivity, inappropriate diet (lack of fruits-vegetables, refined sugar, animal fat and protein, starvation, social inequalities, cigarette smoking, alcohol intake were significantly and positively associated with diabetes in general and type 2 diabetes in particular.

Conclusion: The high prevalence of diabetes is due to the unexpected high rates of type 2 diabetes, aging, urbanization, and sedentary lifestyle consequences. The majority of risk factors of diabetes are potentially modifiable by primary prevention.

Key words: Prevalence; type 2 diabetes; sub-Saharan Africa.

\section{Date Accepted for publication: 11th June 2009 Nig J Med 2009; 311 - 320 \\ Copyright $@ 2009$ Nigerian Journal of Medicine}

\section{Introduction}

Diabetes mellitus (DM) is a metabolic disorder characterized by chronic hyperglycaemia resulting from defects of insulin secretion, insulin action, or a combination of both ${ }^{1}$. Currently, it is estimated that 246 million people throughout the world have diabetes. This prevalence will increase to 380 million, may be even to 500 million, by $2030^{2,3}$. Classification of DM includes aetiological types and different clinical stages of hyperglycaemia ${ }^{4}$. Four main aetiological categories have been defined as type 1 diabetes mellitus (T1DM), Type 2 diabetes mellitus (T2DM), other specific types, and gestational $\mathrm{Dm}^{5}$.

A clinical study of diabetes from the University Hospital of Kinshasa and published in $1985^{6}$ showed that, T1DM (74\%) was higher than T2DM (26\%). The majority of these patients were males, aged $20-60$ years, lean and from low socioeconomic status. At the same period, malnutrition-related DM (MRDM) was described as a separate form from T2DM and T1DM among tropical populations. However, MRDM is no longer considered as a separate entity, but is included within the other specific Types. The use of specific cut off points to define obesity may help to classify correctly these central Africans lean diabetics.

The objective of this study was to determine the prevalence, classification and risk factors of diabetes mellitus in Kinshasa Hinterland.

\section{Materials and Methods}

\section{Design of study}

This cross-sectional survey was conducted between January and April, 2005, in the Kinshasa Hinterland. The study protocol was approved by the Kinshasa University School of Medicine Committee of Ethics. Campaigns of information and sensitization of the general population were delivered during December, 2004, using media (Radio, TV, churches and Tribe Leaders).

Correspondence to LONGO-MBENZA Benjamin, longombenza@yahoo.fr 


\section{Target population and sampling}

Figure 1 presents the target population from Kinshasa Hinterland (Former Province State of Leopoldville), the South-West zone of DRC including 3 administrative regions (Kinshasa Region, Bas-Congo Region and Bandundu Region) with 12 million inhabitants and enjoying tropical climate. Kinshasa Hinterland is defined by a representative multi-ethnic population, 12 developed Zones and 12 underdeveloped zones. Each zone is divided into enumeration districts (ED or localities) taking as primary sampling units.

The survey was specifically and extensively designed using a statistical multistage and stratified random model at each level to recruit a study sample (Figure 1) with similar and representative characteristics of Kinshasa Hinterland demographic and socioeconomic structure ${ }^{7-10}$ and results comparable with global data on DM. The sample size was calculated: $Z^{2} \times p \times q \times f / d^{2} x$ 8.5 where Z: 1.96 at error risk of $5 \%$; $p$ : expected prevalence of DM in each area; q: 1-p; d: absolute accuracy of $2 \% ; f: 8.5$ to correct design effect.

\section{Data collection}

In the last week of December, 2004, a workshop was held concurrently in Kinshasa city (Université de Kinshasa et Lomo Médical Center) and Kikwit (Université de Bandundu / Extension Université de Kinshasa) to standardize the protocol and methodology (administering the questionnaires, drawing blood, and taking measurements). Thus, a 3day training course to use a WHO STEPS approach specially prepared manual with recommendations for non-communicable diseases survey protocols ${ }^{10,}{ }^{11}$, took place for the investigators (diabetologist, cardiologist, epidemiologists, physicians, trained nurses and medical students) in each setting before this survey.

After verbal or written informed consent was obtained, participants were taken through a structured questionnaire administered during 30 minutes in one session for recording the day before physical examination. Information on demographic data (age, sex), smoking habit, alcohol intake, physical activity, residence environment (upper urban, urban, rural, deepest rural), diet (tea and milk, fruits-vegetables protein intake, etc), means transportation, psychosocial stress, exercise, health history, education level, monthly income, and time of sitting position in office or watching television.
Body weight in light clothes was measured to the nearest $100 \mathrm{~g}(0.1 \mathrm{~kg})$ using a Soehnle scale (SoenleWaagen Gmbh Co, Murrhardt, Germany), and height was recorded to the nearest $0.5 \mathrm{~cm}$ using portable locally manufactured stadiometers. Participants stood upright on a flat surface without shoes, with the back of the heels and the occiput on the stadiometer. Body mass index (BMI) was calculated as weight divided by height squared $\left(\mathrm{kg} / \mathrm{m}^{2}\right)$. Waist circumference (WC) was measured after gentle expiration between the lower rib margins and the iliac crest to the nearest millimetre using a flexible tape, with subjects standing with their heels together. Standardized protocols were used to measure both body weight, height and waist circumference $^{12-14}$ with appropriate validation and quality-control procedures. Blood pressure was defined as the average of the last two measurements with a standard mercury sphygmomanometer taken at intervals longer than 2 minutes after the participants had been sitting for at least 30 minutes according to the American Heart Association guidelines: blood pressure measured with the patient's elbow flexed at heart level.

In each morning before the physical examination between 7.00 AM and 9.00 AM, blood samples were collected by finger puncture for all participants, after a 12 hours confirmed overnight fast. Capillary fasting blood glucose was analyzed immediately with a point-of-care analyzer (cholestec LDX, Hayward, USA) ${ }^{15}$. If glucose was $=5.6 \mathrm{mmol} / \mathrm{L}$ and the participant was not aware of having DM, additional capillary measurement was performed within 10 minutes with a glucometer (Ascencia Elite, Bayer Germany) that adjusts readings to plasma values and the mean of the two readings was considered $^{16}$. Participants without DM were once more encouraged to undergo 2 days after, a $2 \mathrm{~h}$ postprandial glucose test (regular meal). One week before, 350 subjects had been simple randomly selected from the participants without DM and underwent an oral glucose tolerance test or OGTT ( $75 \mathrm{~g}$ glucose in $250 \mathrm{ml}$ of water). Levels of glucose after regular meal and after $75 \mathrm{~g}$ anhydrous glucose correlated well $(r=0.935 ; p<0.0001)$ in this random sub-sample of 350 participants. Inter and intra-assay coefficient of variation (CV) for glucose measurements was $1.3 \%$ and an intra-assay CV of $1.6 \%$, respectively. Each centre participating in the assessment followed internal and external quality control procedures as stipulated by the Korean Society of Quality Control in Clinical Pathology (KSQC) in 1976 / Korean Association of Quality Assurance for Clinical Laboratories (KAQACL) in $1991^{17}$. Thus, the blood determinations performed in the laboratory used were documented to be valid and reliable. 
The fasting concentration of C-peptide was measured by solid phase two-site enzyme immunoassay (ELISA) based on the direct sandwich technique in which two monoclonal antigenic determinants on the C-peptide molecule (Mercodia AB, Sylveiusgatan 8A, SE 75450, Uppsala, Sweden). In each fasting participant, plasma insulin was assayed using Mercodia kits (Mercodia AB, Syl insuiusgaton 8A, SE7450, Uppsala, Sweden).

\section{Definitions}

Ethnic-specific cut-off points with equal importance of pivotal role on the pathophysiology of cardiovascular disease or DM morbidity ${ }^{18}$ were used: Body Mass Index $(\mathrm{BMI})<15 \mathrm{~kg} / \mathrm{m}^{2}$ for malnutrition (undernutrition or underweight), and $\mathrm{WC}=80 \mathrm{~cm}$ for overweight, abdominal obesity level I, specific for Congolese population, men and women both ${ }^{19}$.

Absence of impaired glucose regulation (IGR) I normoglycemia was defined in participants with fasting glucose test $<5.6 \mathrm{mmol}(<100 \mathrm{mg} / \mathrm{dL})$ and $2 \mathrm{~h}$ postprandial glucose test in capillary blood $<7.8 \mathrm{mmol} / \mathrm{L}$ ( $<140 \mathrm{mg} / \mathrm{dL}$ ) . Impaired Fasting Glucose (IFG) was defined with fasting glycemia $=5.6 \mathrm{mmol} / \mathrm{L}(=100 \mathrm{mg} / \mathrm{dL})$ and $<7 \mathrm{mmol} / \mathrm{L}(<126 \mathrm{mg} / \mathrm{dL})$, and $2 \mathrm{~h}$ postprandial glucose test in capillary blood $<7.8 \mathrm{mmol} / \mathrm{L}(<140 \mathrm{mg} / \mathrm{dL})$; Impaired Glucose Tolerance (IGT) with $2 \mathrm{~h}$ postprandial glucose test $=7.8-11 \mathrm{mmol} / \mathrm{L}(140-199 \mathrm{mg} / \mathrm{dL}) ; \mathrm{DM}$ with fasting glycemia $=7 \mathrm{mmol} / \mathrm{L}(=126 \mathrm{mg} / \mathrm{dL})$ or $2 \mathrm{~h}$ postprandial glucose test $=11.1 \mathrm{mmol} / \mathrm{L}(=200 \mathrm{mg} / \mathrm{dL}){ }^{20}$. Indeed, participants with known DM have medical history of DM confirmed by a record review conducted at the offices of their Primary care centers, taking insulin or oral diabetic medication.

The following demographic, socio-economic and environmental factors were considered: age groups, sex, completed education level (illiteracy: 0 year schooling, primary:1-8 years schooling, secondary: 12 years schooling, and superior/University = 16 years schooling), residence environment (urban residence for living in the metropolitan region of Kinshasa city vs. rural residence for living in the provincial region of Kikwit for more than 1 year, respectively), monthly household income in USA Dollar ( $<100$ USD for Tertile I, 100-599 USD for Tertile II, and = 600USD for Tertile III). The levels of socio-economic status (SES) were defined by a composite scale value of the urbanization degrees, education attainment, goods, salary, and household income; very high SES (Tertile III with score $=66$ points), moderate SES (Tertile II: score 3365 points), and low SES (Tertile I; score $<33$ points) $)^{21}$. Pooled very high SES and moderate SES defined high
SES versus low SES. Acculturation/Westernization levels were defined by a composure scale value of multiethnic marriage, duration of urban exposure, electricity and water supply, and western meals: high for $=10$ versus low for score $<10$.

Potential risk factors of DM were defined as sex (men vs. women), aging (age $=40$ years vs. $<40$ years), ruralurban migration, physical inactivity ${ }^{22}$, psychosocial stress (social insecurity/anxiety measured by the number dependents in each family, degree of responsibility, position in the organization and civil status) $^{10}$ tea and milk intake at breakfast vs. other (coffee, traditional habitual cassava or maize meal), social inequalities in terms of socioeconomic status (SES), animal fat and protein intake vs. no intake, current cigarette smoking (yes vs. no), personal histories of malnutrition/kwashiorkor or viral parotiditis in childhood, current malnutrition $\left(\mathrm{BMI}<18.5 \mathrm{~kg} / \mathrm{m}^{2}\right)$ or total obesity $\left(\mathrm{BMl}=30 \mathrm{~kg} / \mathrm{m}^{2}\right)^{23}$, abdominal obesity defined by $W C=102 \mathrm{~cm}$ for men and $W C=88 \mathrm{~cm}$ for women according to NCEP-ATPIII thresholds ${ }^{24}$, and arterial hypertension (blood pressure $=140 / 90 \mathrm{mmHg}$ ) from the average of two readings separated by 2 min each, and/or medical history of hypertension. A new class for individuals between normal blood pressure and definite arterial hypertension has been named Prehypertension: SBP between $120 \mathrm{mmHg}$ and $139 \mathrm{mmHg}$ and/or DBP 80 and $89 \mathrm{mmHg}^{25,26}$. Physical inactivity was defined by levels 1 and 2 of WHO/CPAQ (Global Physical Activity Questionnaire) using Comparative risk assessment (CRA) methodology (no or very little physical activity at work, at home, for transport, during discretionary time, doing some physical activity but less than 150 minutes of moderate-intensity or 60 minutes of vigorousintensity a week accumulated across work, home) whereas active participants were defined by level 3 of WHO/CPAQ using CRA methodology (sufficiently active, unexposed participants) ${ }^{22,27}$.

Ethnic-specific cut-off points with equal importance of pivotal role on the pathophysiology of cardiovascular disease or DM morbidity ${ }^{18}$ were used: $I M C=15 \mathrm{~kg} / \mathrm{m}^{2}$ for malnutrition (undernutrition or underweight), and $\mathrm{WC}=80 \mathrm{~cm}$ for overweight, abdominal obesity level $\mathrm{I}^{19}$.

The levels of SES (high for Tertile 3, moderate for Tertile 2 , and low for Tertile 1) were defined using a composite scale value scores ${ }^{10}$ according to the stage of urbanization (westernization, electricity, water supply, types of houses), income, and education level. Globally, urban residence was defined for the participants living in 
Kinshasa metropolitan area vs. rural residence in those living outside the metropolitan area for more than 1 year, respectively.

The cardiometabolic risk often associated with urbanization, lifestyle changes, and behavioural habits comprised total obesity, abdominal obesity defined by $W C=94 \mathrm{~cm}$ for both men and women ${ }^{19}$, and arterial hypertension defined according to Joint National Committee recommendations ${ }^{26}$.

The following statistically derived syntaxes served to classify the types of DM:

- compute type $1 \mathrm{~B} D M=0$. if (age $<40$ years and BMI $<23 \mathrm{~kg} / \mathrm{m}^{2}$ and insulin therapy used to control DM and (presence of ketoacidosis or late macoangiopathy and microangiopathy complications));

- compute type 1A DM=0. if (age $=25$ years and BMI $>23 \mathrm{~kg} / \mathrm{m}^{2}$ and other autoimmune disorders and individuals became dependent on insulin after many years of cell function sufficient to prevent ketoacidosis);

- compute type $2 \mathrm{DM}=0$. if $\left(\left(\mathrm{BMI}=15 \mathrm{~kg} / \mathrm{m}^{2}\right.\right.$ or $\mathrm{WC}=80$ $\mathrm{cm})$ and age $=40$ years and individuals nondependent on insulin and earlier development of macrovascular/microvascular complications and ketoacidosis seldom occurs);

- compute non classified $D M=0$. if (type $1 B D M=0$ and type $1 \mathrm{ADM}=0$ and type $2 \mathrm{DM}=0$ and specific $\mathrm{DM}=0$ );

- compute specific $D M=0$. if (history of infant protein malnutrition or presence of either viral infections or endocrinopathy or Drug/chemical-induced diabetes) and type $1 \mathrm{ADM}=0$ and type $2 \mathrm{DM}=0$ ).

The participants with undetermined DM form as nonclassified DM using WHO/ADA classification, had Fasting insulin and C-peptide levels normal or elevated (plasma insulin $=2 \mu \mathrm{U} / \mathrm{mL}$ and C-peptide $>0,8 \mathrm{pmol} / \mathrm{mL}$ ) in comparison with participants classified as T2DM using the same criteria ${ }^{28,29}$.

The body composition for each participant included the total body water (TBW) calculated by the regression equation of Mellits and Check $^{30}$ from deuterium oxide measurements [TBW in litres 5210.31310.252 (weight in kg) 10.154 (height in $\mathrm{cm}$ ) when $=110 \mathrm{~cm}$ ]; the lean body mass (LBM) in $\mathrm{kg}$ was derived from the method of Pace and Rathbun ${ }^{31}$ [LBM in $\mathrm{kg} 50.72$ (weight in $\mathrm{kg}$ )], and the body fat mass (BFM 5 body weight in $\mathrm{kg} 2 \mathrm{LBM}$ in $\mathrm{kg}$ ).

\section{Statistical analysis}

Data were summarized by calculating means \pm SD for quantitative variables and proportions for categorical variables. Chi-square test was used to compare proportions while Student t-test and ANOVA served to compare means between groups. Within group comparisons were made using a t-test with Bonferroni adjustment for multiple tests. Kappa served to measure the concordance between statistical derived syntaxes and residual insulin secretion to classify diabetes types. Odds ratios were calculated with 95\% confidence intervals $(\mathrm{Cl})$ using univariate (contingency table) and multivariate (logistic regression) analyses with classic types of DM as dependent variables. $P$ for trend was calculated to show any biological gradient (dose effect) of predictors on the presence of types of DM. The DM prevalence estimate was age-standardized according to the WHO Steps ${ }^{11}$. A P value $<0.05$ was considered as statistically significant. All data analyses were performed with the SPSS package for Windows version 13.0 (SPSS In, Chicago, Illinois, USA).

\section{Results}

The study population comprised 9770 participants with 4580 men (46.9\%), 5190 women (53.1\%), and with a mean age of $46 \pm 15$ years (range 12 to 98 years).

\section{Crude prevalence of stages and types of DM}

Overall crude and age adjusted prevalences of DM were $25 \%(n=2472)$ and $18 \%$, respectively. Only $25.8 \%$ of diabetics $(n=850)$ were known diabetics. Figure 2 presents the distribution of diabetes according WHO/ADA classification: over $10 \%$ of DM were undetermined (non-classified). However, the total rate of T2DM defined by Fasting insulin and C-peptide levels normal or elevated (plasma insulin $=2 \mu \mathrm{U} / \mathrm{mL}$ and Cpeptide $>0,8 \mathrm{pmol} / \mathrm{mL}$ ) was estimated $92 \%$ among all diabetes. The Kappa statistic between statistical derived syntaxes and residual insulin secretion to classify the DM types was 1. $(P<0.0001)$.

Table 1 shows that both classic type 2 DM and nonclassified DM were the same class of DM according to body composition, WC, DBP, and fat although individuals with non classified DM were younger, heavier (higher levels of body weight and BMI), with lower SBP.

\section{Risk factors and classic types of DM}

Table II presents univariate associations between risk factors and classic types of DM. Physical inactivity and the daily intake of tea and milk at breakfast were positively associated with each type of DM, respectively. There was a significant association between type 2, specific DM, and urban residence. Low intake of fruits- 
vegetables was a risk factor of type $2 \mathrm{DM}$, type $1 \mathrm{~A} D \mathrm{DM}$, and type 1B DM. Both high intake of refined sugar, alcohol intake and motorised means of transportation were the risk factors of type $2 \mathrm{DM}$ and type $1 \mathrm{ADM}$. current cigarette smoking and high intake of animal fat and protein were the risk factors of type $2 \mathrm{DM}$. However, there was no significant influence of sex on the prevalences of the different types of DM.

The relationship between DM and other cardiometabolic risk factors is shown in Table 4. Only type 1A DM was significantly associated with total obesity. There was a significant relationship between type 1B, type 2DM, and abdominal obesity. Arterial hypertension was a significant risk factor of both type 1ADM and type $2 \mathrm{DM}$. Specific DM was absent in each cardiometabolic risk factor.

Biological gradient, curvilinear relationship, and types of DM

Figure 2 displays the relationships between age, weekly frequency of butter, other animal fat, and animals fat intake, and types of DM. Type 1ADM did not vary with age ( $P$ for trend=0.566) and weekly frequency of butter, other animal fat, and animals fat intake ( $P$ for trend $=0.689$ ). There was a significant and negative association between specific DM and age groups ( $P$ trend $<0.0001$ ). There was a significant and positive association between type 1B DM ( $P$ trend<0.001), type 2 DM ( $P$ trend $<0.0001)$, and ageing process. There was a significant and positive association between type $2 \mathrm{DM}$ and increasing weekly frequency of botter, other and animals fat intake. However, there was no specific DM ( $P$ trend $=0.291$ ), type 1B DM ( $P$ trend $=0.118)$, and increasing weekly intake of butter, other animals fat intake.

A significant $U$-shaped relationship was shown between education levels $(P<0.0001$ and $P$ trend $=0.236)$, monthly income $(P<0.0001$ and $P$ trend $=0.574)$, frequency of daily meals intake $(P<0.0001$ and $P$ trend $=0.05)$; and type 2 DM (Figure 3). However, specific DM was not significantly influenced by education levels $(P=0.524$ and $P$ trend=0.827), monthly income $(P=0.876$ and $P$ trend $=0.998$ ), and frequency of daily meals intake $(P=0.631$ and $P$ trend $=0.396)$, respectively. Furthermore, type $1 \mathrm{~A}$ DM prevalence increased with education levels $(P=0.004$ and $P$ trend $=0.007)$, monthly income $(P=0.005$ and $P$ trend $<0.0001$ ), and frequency of daily meals intake $(P=0.02$ and $P$ trend $=0.04)$. Type $1 B D M$ prevalence increased with education level $(P<0.01$ and $P$ trend $=0.07)$, monthly income $(P=0.006$ and $P$ trend $<0.0001)$, but not with frequency of daily meals intake. Independent risk factors of type 2DM
Adjusted for sex, age, history of DM, education, and alcohol intake, high SES, high level of acculturation/westernization, current cigarette smoking, high intake of animal fat and protein, urban residence, physical inactivity, low intake of fruitsvegetables, high intake of tea and milk at breakfast were identified as significant and independent risk factors of type 2 DM (Table V). The same significant association was observed in predicting non-classified DM (results not shown) and the prevalence of total prevalence of DM (results not shown).

Table I. Age, blood pressure, and body composition and size of type 2 diabetes mellitus versus non classified diabetes mellitus

$\begin{array}{llll}\begin{array}{l}\text { Variables of interest } \\ =380\end{array} & \begin{array}{l}\text { Classic type 2 DM n=2620 } \\ \text { P value }\end{array} & \text { Non classified DM } & \\ \text { Age }(\text { years }) & 53 \pm 13 & 32 \pm 10 & 0.009 \\ \text { Weight }(\mathrm{kg}) & 66 \pm 14 & 67 \pm 20 & 0.023 \\ \text { Height }(\mathrm{m}) & 1.675 \pm 0.100 & 1.676 \pm 0.09 & 0.283 \\ \text { BMl }\left(\mathrm{kg} / \mathrm{m}^{2}\right) & 24 \pm 5 & 25 \pm 7 & 0.029 \\ \text { WC }(\mathrm{cm}) & 84 \pm 16 & 82 \pm 15 & 0.667 \\ \text { Conicity Index } & 0.613 \pm 0.272 & 0.568 \pm 249 & 0.330 \\ \text { SBP }(\mathrm{mmHg}) & 126 \pm 28 & 114 \pm 16 & 0.028 \\ \text { DBP }(\mathrm{mmHg}) & 77 \pm 15 & 72 \pm 15 & 0.816 \\ \text { Percent body fat }(\%) & 30 \pm 9 & 24 \pm 11 & 0.507 \\ \text { Body fat }(\mathrm{kg}) & 17 \pm 10 & 21 \pm 13 & 0.232 \\ \text { BSA }\left(\mathrm{m}^{2}\right) & 1.740 \pm 0.187 & 1.740 \pm 0.234 & 0.247 \\ \text { Ideal weight }(\mathrm{kg}) & 61 \pm 7 & 61 \pm 7 & 0.830 \\ \text { Lean body mass }(\mathrm{kg}) & 49 \pm 7 & 49 \pm 9 & 0.105 \\ \text { Total water }(\mathrm{L}) & 33 \pm 4 & 34 \pm 6 & 0.128 \\ \text { Energy expenditure }(\text { Kcal) } & 1397 \pm 189 & 1542 \pm 246 & 0.091 \\ \text { Body nitrogen } & 1417 \pm 201 & 1404 \pm 263 & 0.105\end{array}$

Table II. Relationship between sex, residence, lifestyle changes, and different types of DM

\begin{tabular}{|c|c|c|c|c|}
\hline Variables & $\begin{array}{l}\text { Type 2 DM } \\
\% \text { vs.\% } \\
\text { OR (Cl95\%) } \\
\text { P }\end{array}$ & $\begin{array}{l}\text { Type 1ADM } \\
\text { \% vs.\% } \\
\text { OR (Cl195\%) } \\
\text { P }\end{array}$ & $\begin{array}{l}\text { Type 1B DM } \\
\text { \% vs.\% } \\
\text { OR (CI95\%) } \\
\text { P }\end{array}$ & $\begin{array}{l}\text { Specific DM } \\
\% \text { vs.\% } \\
\text { OR (Cl95\%) } \\
\text { P }\end{array}$ \\
\hline $\begin{array}{l}\text { Sex } \\
\text { Men vs. Women }\end{array}$ & $\begin{array}{l}32.4 \text { vs. } 30.1 \\
P=0.480\end{array}$ & $\begin{array}{l}1.7 \text { vs. } 1.9 \\
P=0.455\end{array}$ & $\begin{array}{l}2.2 \text { vs. } 1.9 \\
P=0.775\end{array}$ & $\begin{array}{l}1.9 \text { vs. } 0.9 \\
P=0.348\end{array}$ \\
\hline $\begin{array}{l}\text { Residence } \\
\text { Urban vs. Rural }\end{array}$ & $\begin{array}{l}26.5 \text { vs. } 44.1 \\
0.5(0.3-0.6)\end{array}$ & $\begin{array}{l}1.5 \text { vs. } 1.6 \\
P=0.956\end{array}$ & $\begin{array}{l}1.7 \text { vs. } 3.1 \\
P=0.323\end{array}$ & $\begin{array}{l}\text { Ovs. } 6.1 \\
\text { P<0.0001 }\end{array}$ \\
\hline $\begin{array}{l}\text { Smoking } \\
\text { Yes vs. No }\end{array}$ & $\begin{array}{l}\text { 44.4 vs. 23.1 } \\
2.7(2-3.6) \\
P<0.001\end{array}$ & $\begin{array}{l}2.2 \text { vs. } 1.2 \\
P=0.380\end{array}$ & $\begin{array}{l}3.3 \text { vs. } 1.5 \\
P=0.155\end{array}$ & $\begin{array}{l}0.6 \text { vs. } 1.7 \\
P=0.265\end{array}$ \\
\hline $\begin{array}{l}\text { Alcohol intake } \\
\text { Yes vs. No }\end{array}$ & $\begin{array}{l}39.8 \text { vs. } 28.8 \\
1.4(1.07-1.9) \\
P=0.041 .9\end{array}$ & $\begin{array}{l}3.6 \text { vs. } 0.3 \\
P=0.002\end{array}$ & $\begin{array}{l}3.1 \text { vs. } 1.4 \\
P=0.142\end{array}$ & $\begin{array}{l}1.8 \text { vs. } 1.1 \\
P=0.470\end{array}$ \\
\hline $\begin{array}{l}\text { Physical inactivity } \\
\text { Yes vs. No }\end{array}$ & $\begin{array}{l}49.2 \text { vs. } 19.3 \\
4(2.9-5.6) \\
P<0.0001\end{array}$ & $\begin{array}{l}4.5 \text { vs. } 0.2 \\
P<0.0001\end{array}$ & $\begin{array}{l}4 \text { vs } 1.2 \\
P=0.03\end{array}$ & $\begin{array}{l}3.4 \text { vs. } 0.5 \\
P=0.005\end{array}$ \\
\hline $\begin{array}{l}\text { Fruits-vegetables intake } \\
\text { Low vs. High }\end{array}$ & $\begin{array}{l}36.5 \text { vs. } 18.4 \\
2.6(1.8-3.7) \\
P<0.0001\end{array}$ & $\begin{array}{l}2.3 \text { vs. } 0 \\
P=0.03\end{array}$ & $\begin{array}{l}5.7 \text { vs. } 0 \\
P<0.0001\end{array}$ & $\begin{array}{l}1.8 \text { vs. } 0.5 \\
P=0.191\end{array}$ \\
\hline $\begin{array}{l}\text { Refined sugar } \\
\text { Low vs. High }\end{array}$ & $\begin{array}{l}40.6 \text { vs. } 20.6 \\
2.6(1.93 .6) \\
P<0.0001\end{array}$ & $\begin{array}{l}0.3 \text { vs. } 2.9 \\
P<0.01\end{array}$ & $\begin{array}{l}1.6 \text { vs. } 2.6 \\
P=0.390\end{array}$ & $\begin{array}{l}1.9 \text { vs. } 0.9 \\
P=0.348\end{array}$ \\
\hline $\begin{array}{l}\text { Tea and milk at breakfast daily } \\
\text { intake }\end{array}$ & & & & \\
\hline Yes vs. No & $\begin{array}{l}54.9 \text { vs. } 24.6 \\
3.7(2.75 .5) \\
P<0.0001\end{array}$ & $\begin{array}{l}4.7 \text { vs } 1 \\
P<0.1\end{array}$ & $\begin{array}{l}5.7 \text { vs. } 1.4 \\
P=0.008\end{array}$ & $\begin{array}{l}9.5 \text { vs } 1 \\
P=0.06\end{array}$ \\
\hline $\begin{array}{l}\text { Transportation mean } \\
\text { Yes vs. No }\end{array}$ & $\begin{array}{l}38.4 \text { vs. } 26 \\
1.8(1.3-2.4) \\
P<0.0001\end{array}$ & $\begin{array}{l}3.1 \text { vs. } 0.6 \\
P<0.01\end{array}$ & $\begin{array}{l}1.8 \text { vs. } 2.2 \\
P=0.766\end{array}$ & $\begin{array}{l}1.4 \text { vs. } 1.4 \\
P=0.998\end{array}$ \\
\hline $\begin{array}{l}\text { Animal fat and Protein intake } \\
\text { High vs. Low }\end{array}$ & $\begin{array}{l}33.6 \text { vs. } 13.3 \\
P<0.0001\end{array}$ & $\begin{array}{l}1.6 \text { vs. } 1 \\
P=0.897\end{array}$ & $\begin{array}{l}4.9 \text { vs. } 2 \\
P=0.209\end{array}$ & $\begin{array}{l}3.3 \text { vs. } 1.2 \\
P=0.379\end{array}$ \\
\hline
\end{tabular}

Table III. Relationship between types of DM and other cardiometabolic risk factors

\begin{tabular}{|c|c|c|c|c|}
\hline Variables & $\begin{array}{l}\text { Specific DM } \\
\% \text { vs.\% } \\
\text { OR (Cl95\%) } \\
\text { P }\end{array}$ & $\begin{array}{l}\text { Type 1A DM } \\
\% \text { vs.\% } \\
\text { OR (Cl95\%) } \\
\text { P }\end{array}$ & $\begin{array}{l}\text { Type 18 DM } \\
\% \text { vs.\% } \\
\text { OR (Cl95\%) } \\
\text { P }\end{array}$ & $\begin{array}{l}\text { Type 2 DM } \\
\% \text { vs.\% } \\
\text { OR (C195\%) } \\
\text { P }\end{array}$ \\
\hline $\begin{array}{l}\text { Total obesity } \\
\quad \text { Presence vs. absence }\end{array}$ & $\begin{array}{l}\begin{array}{l}\text { vs. } 1.6 \\
P=0.257\end{array} \\
\end{array}$ & $\begin{array}{l}4.8 \text { vs. } 1 \\
P=0.009\end{array}$ & $\begin{array}{l}\begin{array}{l}\text { Ovs. } 2.4 \\
P=0.166\end{array} \\
\end{array}$ & $\begin{array}{l}31 \text { v. } 31.2 \\
P=0.969\end{array}$ \\
\hline $\begin{array}{l}\text { Abdominal obesity } \\
\text { Presence vs. absence }\end{array}$ & $\begin{array}{l}\text { Ovs. } 1.6 \\
P=0.241\end{array}$ & $\begin{array}{l}1.2 \text { vs. } 1.6 \\
P=0.762\end{array}$ & $\begin{array}{l}5.6 \text { vs. } 1.4 \\
4.1(1.3-13) \\
P<0.01\end{array}$ & $\begin{array}{l}47 \text { vs. } 28 \\
2.3(1.6-3.3) \\
P<0.0001\end{array}$ \\
\hline $\begin{array}{l}\text { Arterial hypertension } \\
\text { Presence vs. absence }\end{array}$ & $\begin{array}{l}0 \text { vs } 1.4 \\
P=0.612\end{array}$ & $\begin{array}{l}10 \text { vs. } 1.2 \\
9(1.746) \\
\mathrm{P}=0.002\end{array}$ & $\begin{array}{l}5.3 \text { vs. } 1.9 \\
P=0.311\end{array}$ & $\begin{array}{l}68.4 \text { vs. } 28.2 \\
5.5(3-10) \\
P<0.0001 \\
\end{array}$ \\
\hline
\end{tabular}


Table IV. Interaction between genetic and environment in determining the presence of type 2 diabetes mellitus using logistic regression analysis

\begin{tabular}{|c|c|c|c|c|}
\hline Independent variables & $\begin{array}{l}\text { B } \\
\text { Coefficient }\end{array}$ & Standard Error & $\begin{array}{l}\text { OR } \\
\text { (CI 95\%) }\end{array}$ & Pvalue \\
\hline \multicolumn{5}{|l|}{ SES } \\
\hline $\begin{array}{l}\text { Low } \\
\text { High }\end{array}$ & $\begin{array}{l}\text { Reference } \\
2.376\end{array}$ & 0.300 & $\begin{array}{l}1 \\
10.8 \\
(6-19.4)\end{array}$ & $<0.0001$ \\
\hline \multicolumn{5}{|l|}{ Acculturation levels } \\
\hline $\begin{array}{l}\text { Low } \\
\text { High }\end{array}$ & $\begin{array}{l}\text { Reference } \\
2.150\end{array}$ & 0.503 & $\begin{array}{l}1 \\
8.6 \\
(3.2-23)\end{array}$ & $<0.0001$ \\
\hline $\begin{array}{l}\text { Cigarette smoking } \\
\text { Yes vs. No }\end{array}$ & 0.960 & 0.296 & $\begin{array}{l}2.6 \\
(1.5-4.7)\end{array}$ & $<0.001$ \\
\hline $\begin{array}{l}\text { Animal fat and protein intake } \\
\text { High vs. Low }\end{array}$ & 1.466 & 0.521 & $\begin{array}{l}4.3 \\
(1.6-12)\end{array}$ & 0.005 \\
\hline $\begin{array}{l}\text { Residence } \\
\text { Urban vs. Rural }\end{array}$ & 2.288 & 0.429 & $\begin{array}{l}10 \\
(4.3-23)\end{array}$ & $<0.0001$ \\
\hline $\begin{array}{l}\text { Physical inactivity } \\
\text { Yes vs. No }\end{array}$ & 0.686 & 0.284 & $\begin{array}{l}2 \\
(1.14-3.5)\end{array}$ & 0.016 \\
\hline $\begin{array}{l}\text { Fruits-vegetables intake } \\
\text { Low vs. High }\end{array}$ & 0.780 & 0.340 & $\begin{array}{l}2.2 \\
(1.12-4.24)\end{array}$ & 0.022 \\
\hline $\begin{array}{l}\text { Refined sugar intake } \\
\text { Low vs. High }\end{array}$ & 1.509 & 0.303 & $\begin{array}{l}4.5 \\
(2.5-8.2)\end{array}$ & $<0.0001$ \\
\hline $\begin{array}{l}\text { Tea and milk at breakfast da } \\
\text { intake }\end{array}$ & & & & \\
\hline Yes vs. No & 1.215 & 0.353 & $\begin{array}{l}3.4 \\
(1.7-6.7)\end{array}$ & $<0.001$ \\
\hline
\end{tabular}

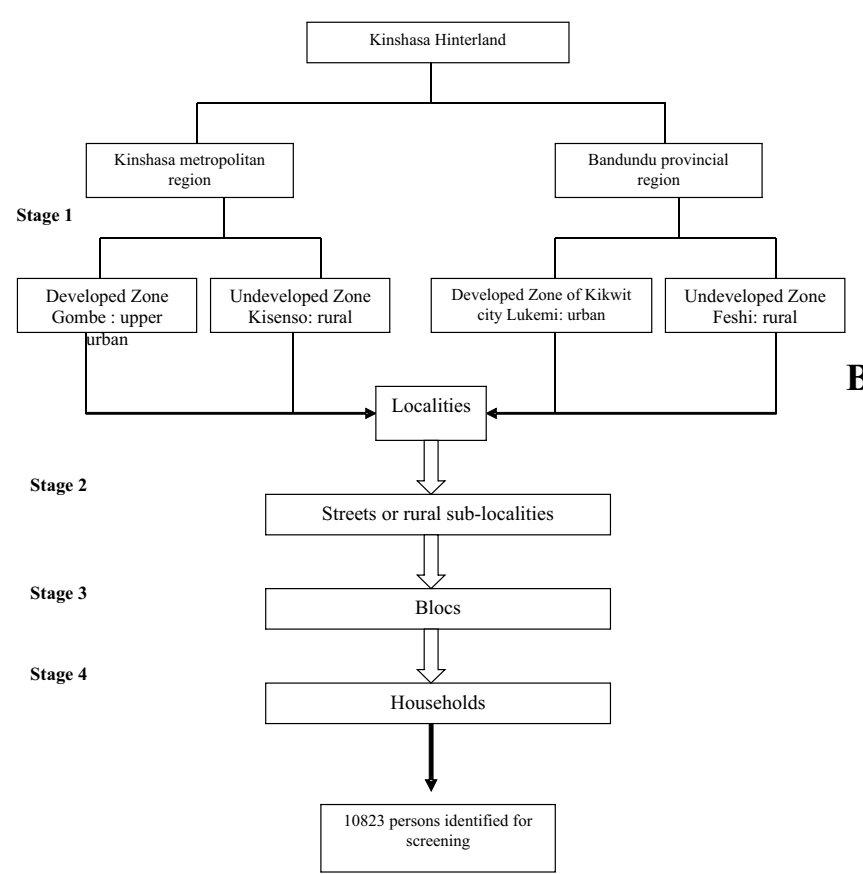

Figure 1: Methodology of probabilistic sampling design.

口specific DM

口Non classified DM

口Type 1A DM

口Type $1 B \mathrm{DM}$

-Type 2 DM

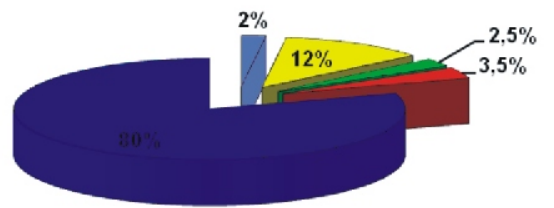

Figure 2. Classification of diabetes mellitus (DM) among 3290 cases of DM in Kinshasa Hinterland.
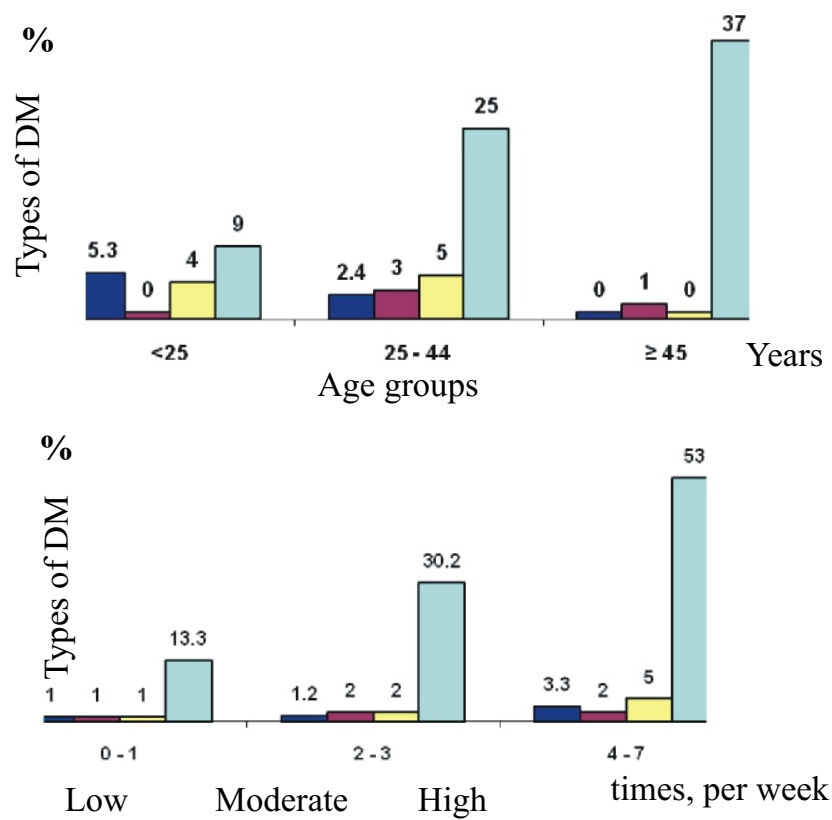

Figure 3. Relationship between age groups, frequency of botter, other animal fat and visceral intake and different types of DM: specific DM ( $\square)$, type $1 \mathrm{~A}$ $(\square)$, type 1B ( $\square)$, Type 2( $\square)$.
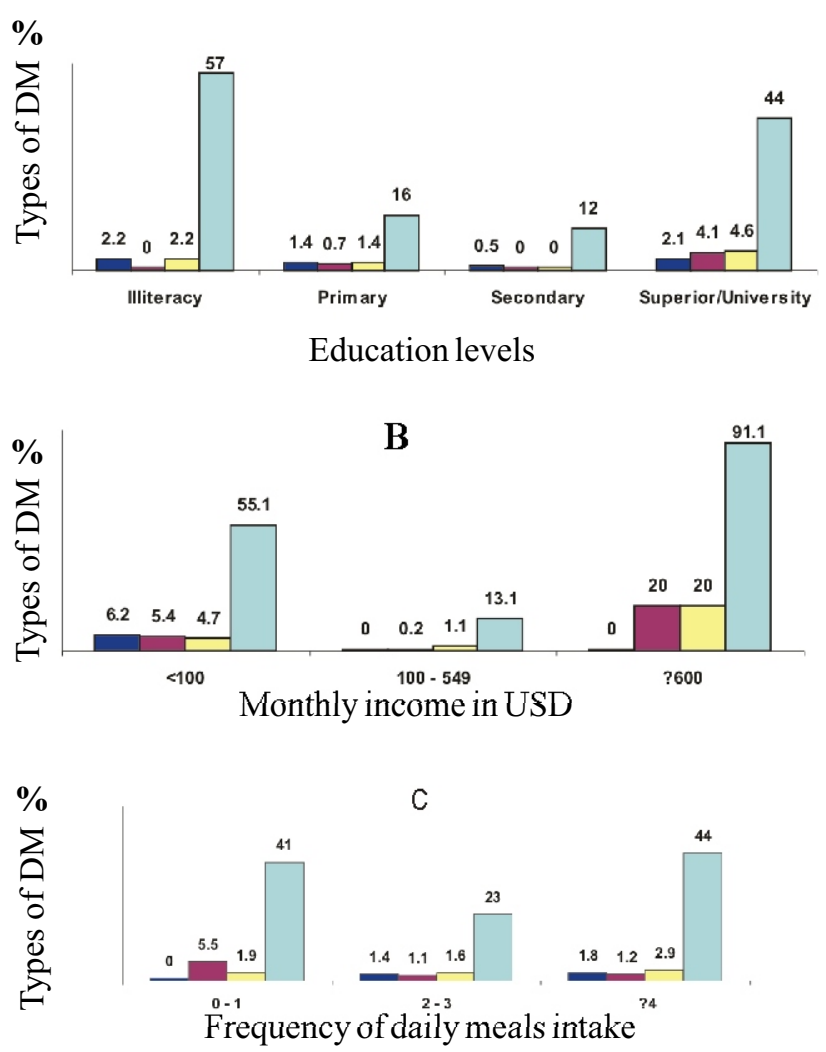

Figure 4. Relationship between education levels, monthly income, frequency of daily meals intake and different types of DM: specific DM ( $\square)$, type $1 \mathrm{~A}$ $(\square)$, type 1B ( $\square)$, Type 2( $\square$ ). 


\section{Discussion}

The objective of study was to present the epidemiological aspects related to the prevalence, classification and risk factors of DM in Congolese population.

The present study reports one of the highest rates of DM and Prediabetes in previous and recent studies from Africa ${ }^{32-34}$. We are now far away from 1901, when a missionary physician stated that DM was very uncommon in our central region of Africa ${ }^{35}$. Thus, sub-Saharan Africa will face a double disease burden represented by increasing rates of NCD added to endemic, pandemic, and emergent infections such as malaria, tuberculosis, and HIVIAIDS ${ }^{27}$. Indeed, the recent prevalence of DM in sub-Saharan Africa estimated to be in the range of 1-13\% ${ }^{33,36}$ is lower than this unexpected DM prevalence (crude: $25.3 \%$ adjusted: $17.8 \%$ ).

When classic criteria were considered and gestational DM was not considered, DM was classified into four principal types including type $1 \mathrm{DM}$ (type 1ADM and type 1B DM), type $2 \mathrm{DM}$, other specific types of DM, and non classified DM. As non classified DM was not related to malnutrition but similar to the classic type $2 \mathrm{DM}$, final total type 2DM, type $1 \mathrm{DM}$ (including type $1 \mathrm{~A}$ and type 1B), and specific DM may be considered in these Africans according to the current recommendations of the WHO (1) and $\mathrm{ADA}^{37}$ committees. Thus, the present prevalence of type 2 DM (92\%) confirms the dramatic increase in the prevalence of type $2 \mathrm{DM}$ worldwide ${ }^{2,3,38}$.

There is a dearth of African data concerning the prevalence of type $1 \mathrm{DM}$. This large population survey confirms that type $1 \mathrm{DM}$ is truly rarer in Africa than elsewhere.

The present increases in rate of both T2DM and T1DM indicate the great and urgent need for more epidemiological surveys in sub-Saharan Africa. Such a need is dictated by the prevalence of undiagnosed DM which accounted for $74 \%$ of all diabetics. This undiagnosed DM rate is included within the African range of $6080 \%{ }^{39-41}$. It would therefore appear that in present Africans, for every diagnosed case with $\mathrm{DM}$, there are one to four undiagnosed cases. Underdiagnosis and misdiagnosis of DM may explain the lower DM prevalence reported in previous African studies ${ }^{33}$. Various initiatives and programmes nationally and internationally have been launched to address this rising burden of disease: IDF, WHO, Diabetes UK, Novo Nordisk, World Diabetes Foundation, International Insulin Foundation, national
NGOS, and an 11- point action plan for the African region $^{42}$.

The present findings outline the prominent role of environmental factors in the pathogenesis of DM in comparison with genetic and non modifiable risk factors of $D M$, as reported elsewhere. The dramatic increase in the prevalence of DM in general and in type $2 \mathrm{DM}$ in particular, is a consequence of an impending mass health crisis (organisation of the health system, prevention), a lack of good governance (education, empowerment, community involvement, positive policy environment), globalization, westernization, a sedentary lifestyle, demographic transition (ageing), nutrition transition, urbanization, social inequalities, and behavioural habits.

An equal gender distribution of all types of DM was observed in these urban and rural Congolese as reported in South Africa ${ }^{43}$, urban Tanzania ${ }^{44}$, and global estimates $^{45}$. The sex ratio of the DM prevalence varies within and between populations with no obvious trend: a male preponderance in rural Cameroonians ${ }^{39}$ contrasting with a female excess in $\mathrm{Mali}^{46}$.

Specific DM decreased with age and type 1B DM increased with age. Both specific DM, type $1 A D M$, and type 1B DM had their peak age of onset before 45 years and were absent after the age of 45 years as reported in Europeans ${ }^{47}$. African studies indicate that the age of onset is later ${ }^{48}$ than elsewhere ${ }^{47}$. Speculative explanations come from prolonged breast feeding in sub-Saharan Africa which may reduce the incidence and delay the onset of type $1 \mathrm{DM}$. Early introduction of cow's milk protein may be a risk factor for the later development of type 1 DM (albumin-induced antibodies against pancreatic beta cells).

Type 2 DM prevalence in these Congolese increased significantly with age with the peak of occurrence in the age $=45$ years as observed in developed countries ${ }^{10}$. This situation is a result of demographic change: older age structures. Age-specific levels of DM in many urban areas of sub-Saharan Africa have become as high as, or higher than those from developed countries ${ }^{41}$. However, in this study, age was not found to be a significant and independent risk factor for type $2 \mathrm{DM}$; contrasting with previous African studies ${ }^{43}$.

The present association between age, environmental risk factors, and different types of DM may explain the difficulty to discriminate type $1 \mathrm{DM}$ from type $2 \mathrm{DM}^{6}$. 
This study supports the existence of the prominent role of an environmental "trigger" factors as risks of both type 1 DM and type 2 DM. Environment (urbanization, social inequalities, lifestyle changes and consequences, behavioural habits) but not family history of DM, age, and gender, determines DM prevalence in these African Bantu of similar genetic origin. Urban residence, acculturation/westernization, abdominal obesity, systemic arterial hypertension, high SES, physical inactivity, low intake of fruits-vegetables, high intake of animal fat and protein, cigarette smoking established consequences of globalization, industrialization and Health transition (lifestyle changes) ${ }^{34}$ were the significant risk factors of type $2 \mathrm{DM}$ and total prevalence of DM as reported in many African studies ${ }^{33}$.

Findings from this study confirm the obsolete role of BMI in predicting independently the cardiometabolic risk in this sub-Saharan African setting ${ }^{48}$. Indeed, BMI measures total body mass, both fat and lean mass whereas WC is used as a proxy measure for fat distribution (abdominal obesity)/Insulin resistance ${ }^{49}$.

The U-shaped relationship between education level, monthly income, frequency of daily meals, and type $2 \mathrm{DM}$ is not easy to explain in this study. The present results contrast with the strong inverse association between SES and the prevalence of DM in developed countries ${ }^{49,50}$. In this study, both low SES and high SES were associated to the high risk of DM. Low intake of fruits and vegetables (lack of anti-oxidants) in low SES and consumption of milk

\section{References}

1. WHO CONSULATION.Definition, diagnosis and classification of diabetes mellitus. Report n99.2.Geneva: World Health Organization; 1999.

2. A consensus statement from the International Diabetes Federation. Diabet Med 2006;23:469-80. www.eatlas.idf.org/media.

3. WILD S, ROGLIC G, GREEN A, SICREE R, KING H. Global prevalence of diabetes: estimates for the year 2000 and projections for 2030. Diabetes care 2004; 27:1047-1053.

4. KUZUYA T, MATSUDAA. Classification of diabetes on the basis of aetiologies versus degree of insulin deficiency. Diabetes care 1997;20:219-220.

5. The Expert Committee on the Diagnosis and Classification of Diabetes Mellitus: Follow-up report on the diagnosis of diabetes mellitus. Diabetes Care 26:31603167, 2003

6. KANDJINGU K, BIELELIE, BIDINGIJAM, DITU M, TSHIANI KA. Clinical study of diabetes mellitus in Kinshasa. Médecine d'Afrique noire 1985;32(3):53-61.

7. DEMOCRATIC REPUBLIC OF CONGO. National survey of children and women situation. MICS2 2001. Say yes for children, Kinshasa, USAID/WHO/UNICEF:2, 40 46, 2002. (reduction of anti-oxidant effect of black tea) ${ }^{51}$ and the high intake of animal fat in high SES, may determine important oxidative stress implicated in T2DM.

\section{Limitations}

Although its cross-sectional approach, this study avoided many constraints through huge size and survey area. This study was limited by the lack of markers of immune destruction cell: autoantibodies, autoantibodies to insulin, autoantibodies to glutamic acid decarboxylase and autoantibodies to the tyrosine phosphatases.

\section{Conclusion}

The present dramatic epidemic of DM in general and that of type 2 DM in particular ( $92 \%$ of all cases), are a result of demographic, nutrition, and epidemiologic transition: older age structures, urbanization, westernization, inappropriate diet, sedentary lifestyle changes, abdominal obesity, systemic arterial hypertension, cigarette smoking, excessive alcohol intake outstripping infectious and malnutrition diseases.

The WHO/ADA classification is not useful among Congolese diabetics. Urgent program of prevention and management of DM are needed.

\section{Acknowledgements}

We thank the many people involved in facilitating the findings reported by this study, through fieldwork and technical assistance.

8. NGONDO A, PITSHANDENGE S. Demographic perspectives of Zaïre during 1984 1999. Cedas 1984; 1:31-32.

9. NATIONAL PROGRAM OF NUTRITION. Nutrition survey in Kinshasa Hinterland region, March 2004. Democratic Republic of Congo, Ministry of health 2004; 100-106

10. LONGO-MBENZA B, VANGU NGOMA D, NAHIMANA D, MUPEPE MAYUKU D, MBUNGU FUELE S, EKWANZALA F, BEYAC. Screen detected and the WHO Stepwise approach to the prevalence and risk factors of arterial hypertension in Kinshasa. Eur J cardiovasc Prev Rehabil 2008; 15(5):503508.

11. WHO: WHO/NMH/CCS/03.04. STEPS planning and implementation. The WHO STEPwise approach in the management of non communicable diseases and mental health, 2006.

12. LOHMAN TG, ROCHE AF, MARTORELL R. Anthropometric standardization reference Manual Champaign, IL, Human kinetics 1998; 3-8, 39-70 
13. WANG J, THORNTON JC, BARI S, WILLIAMSON B, GALLAGHER D, HEYMSFIELD SB, HORLICK MN, KOTLER DP, LAFERRERE B, MAYER L, PI-SUNYER FX, PIERSON RN JR. Comparison of waist circumferences measured at four sites. Am J Clin Nutr 2003; 77:379-384.

14. WHO: OBESITY. Preventing and managing the global epidemic: report of WHO consultation on obesity, 35 June, 1997, Geneva: WHO, 2006.

15. PRICE C. Point-of-care testing in diabetes mellitus. Clin Chem Lab Med 2003; 41: 1213-9.

16. FAEH D, WILLIAM J, TAPPY L, RAVUSSIN E, BOVET P. Prevalence, awareness and control of diabetes in the Seychelles and relationship with excess body weight. BMC Public Health 2007; 7: 163.

17. $\mathrm{CHO} \mathrm{HI}$. Twenty-years of experiences in external quality assurance in Korea. Korean Association of Quality Assurance for Clinical Laboratories (KAQACL).Southeast Asian J Trop Med Public Health 1999; 30 (Suppl3): 32-8.

18. Banerjee D, Misra A. Does using ethnic specific criteria improve the usefulness of the term metabolic syndrome? Controversies and suggestions. Int J Obes 2007;31(9):1340-9.

19. KASIAM L, LONGO-MBENZA B, NGE OKWE A, MBUNGU FUELE S. Survey of abdominal obesities in an adult urban population of Kinshasa, Democratic Republic of Congo. Cardiovasc JAfr 2007; 18: 300-307.

20. THE EXPERT COMMITTEE ON THE DIAGNOSIS AND CLASSIFICATION OF DIABETES MELLITUS. Report of the expert committee on the diagnosis and classification of diabetes mellitus.

1. Diabetes care 2003; 26 (Suppl 1): S5 S20.

21. LONGO-MBENZA B, NKOY BELILA J, VANGU NGOMA D, MBUNGU S: Prevalence and risk factors of arterial hypertension among urban Africans in workplace: the obsolete role of body mass index. Niger J Med 2007;16(1):42-49.

22. Joubert J, Norman R, Lambert EV, Groenewald P, Schneider M, Bull F, Bradshaw D and the South African Comparative Risk Assessment Collaborating Group. Estimating the burden of disease attributable to physical inactivity in South Africa in 2000. Samj 2007; 97(8): 725-31.

23. Clinical guidelines on the identification, evaluation, and treatment of overweight and obesity in adults: executive summary. Expert Panel on the Identification, Evaluation, and Treatment of Overweight in Adults.Am J Clin Nutr 1998 (oct); 68 (4): 899-917.

24. EXPERT PANEL ON DETECTION, EVALUATION AND TREATMENT OF HIGH BLOOD CHOLESTEROL IN ADULTS. Executive summary of the third report of the National Cholesterol Education Program (NCEP) Expert Panel on detection, Evaluation and Treatment of High Blood Cholesterol in Adults (Adult Treatment Panel III).JAMA 2001;285:2486-97.

25. GUIDELINES SUB-COMMITTEE 1999. world Health Organization: International Society of Hypertension. Guidelines for the Management of Hypertension. J Hypertens 1999;17: 151183.

26. JNC VIII. The seventh report of the Joint National Committee on prevention, detection, evaluation and treatment of high blood pressure: NIH Publication $n^{\circ} 04-5230$. Washington, DC: US Department of Health and Human Services; 2004.

27. Bull F, Amstrong TP, Dixon T, Ham S, Neiman A, Pratt M. Physical inactivity. In : Ezzati M, Lopez AD, Rodgers A, Murray CJL, eds. Comparative Quantification of Health Risks: Global and Regional Burden of Disease Attributable in Slected Major Risk Factors. Vol 1. Geneva: World Health Organization 2004; 729881.
28. . Laakso M. How good a marker is insulin level for insulin resistance?Am J Epidemiol 1993; 137: 959-65.

29. Kahn SE, Prigeon RL, McCulloch DK, Boyko EJ, Bergman RN, Schwartz MW, Neifing _JL, Ward WK, Beard JC, Palmer JP, et al. Quantification of the relationship between insulin sensitivity and beta-cell function in human subjects. Evidence for a hyperbolic function. Diabetes 1993; 42(11): 1663-72.

30. Mellits ED, Cheek DB. The assessment of body water and fatness from infancy to adulthood. In: Brozek J, ed. Physical Growth and Body Composition. Monogr Soc Res Child Dev 1970; 35(7): 1226.

31. Pace N, Rathbun EW. Studies on body composition III. The body water and chemically combined nitrogen content in relation to fat content. J Biol Chem 1945; 158: 685-691.

32. AMOAH AG, OWUSU K, ADJEI S. Diabetes in Ghana: $A$ community based Prevalence study in greater Accra. Diabetes Research and Clinical Practice 2002; 56:197-205.

33. SOBNGWI E, MAUVAIS-JARVIS E, VEXIAU P, MBANYA JC, GAUTIER JF. Diabetes in Africans. Part 1 :Epidemiology and clinical specificities.

2. Diabetes and Metabolism 2001;27:628-634.

34. MOSLEY WH, BOBADILLA JL, JAMISON DT. "The Health transition: implications for Health Policy in developing countries". In Jamison DT (eds). Disease control priorities in developing countries. New-York: Oxford University Press 1993:673-699.

35. COOK AR. Notes on the diseases met with in Uganda, central Africa. J trop med 1901:4:175-178.

36. BALDE NM, DIALLO I, BALDE MD et al. Diabetes and impaired fasting glucose in rural and populations in Futa Jallon (Guinea): prevalence and associated risk factors.

3. Diabetes Metabolism 2007:33:114-120.

37. ALBERTI KGMM, ZIMMET O for the WHO Consultation, Definition, Diagnosis and Classification of Diabetes mellitus and its complications. Part I: diagnosis and classification of diabetes mellitus. Provisional Report of a WHO Consultation. Diabetic Med; 15:539-553.

38. ZIMMET P, ALBERTI KGMM, SHAW J. Global and societal implications of the diabetes epidemic. Nature 2001;414: 782787.

39. MBANYA JC, NGOGANG J, SALAH JN, MINKOULOU E, BALKAUB.

4. Prevalence of NIDDM and impaired glucose tolerance in a rural and an urban population in Cameroon. Diabetologica 1997; 40: 824-829.

40. AMOAH AG, OWUSU SK, ADJEI S. Diabetes in Ghana: A Community based prevalence study in greater Accra. Diabetes Research and clinical practice 2002; 56:197-205.

41. ASPRAY TJ, MUGUSI F, RASHID S, WHITING D, EDWARDS KG, ALBERTI KG, UNWIN NC. Rural and urban differences in diabetes prevalence in Tanzania: the role of obesity, physical inactivity and urban living. Transactions of the Royal Society of Tropical Medicine and Hygiene 2000; 94:637-644.

42. BERAN D, YUDKIN JS. Diabetes care in sub-Saharan Africa. Lancet 2006; 368:1689-1695.

43. LEVITT NS, KATZENELLENBOGEN JM, BRADSHAW D, HOFFMAN MN, BONNICI F. The prevalence and identification of risk factors for NIDDM in urban Africans in Cape Town, South Africa. Diabetes Care 1993; 16:601-607.

44. AHREN B, CORRIGAN CB. Prevalence of diabetes mellitus in north-western Tanzania.

5. Diabetologia 1984; 26:333-33. 
45. KING H, REWERS M. WHO AD HOC DIABETES REPORTING GROUP: Global estimates for Prevalence of Diabetes Mellitus and Impaired Glucose Tolerance in Adults. Diabetes Care 1993;16: 157-176.

46. FISCH A, PICHARD E, PRAZUCK T, LEBLANC H, SIDIBE Y, BRUCKER G. Prevalence and risk factors of diabetes mellitus in the rural region of Mali (West Africa): a practical approach. Diabetologia 1987;30: 859-862.

47. KALK WJ, HUDDLE KRL, RAAL FJ. The age of onset of insulindependent diabetes mellitus in Africans in South Africa. Postgraduate Medical Journal 1993;69:552-556.

48. LESTER FT. The clinical pattern of diabetes in Ethiopians.

6. Diabetes care $1984 ; 7: 6-11$.
49. KALK WJ, HUDDLE KRL, RAAL FJ. The age of onset of insulin-dependent diabetes mellitus in Africans in South Africa. Postgraduate Medical Journal 1993:69:552-556.

50. PRESCOTT E, GODFREDSEN N, OSLER M, SCHNOR P, BAREFOOL J. Social gradient in the metabolic not explained by psychosocial and behavioural factors: evidence from the Copenhagen City Heart Study. Eur J Cardiovasc Prev Rehabit 2007; 14:405-412.

51. LORENZ M, BAUMANN G, STANGL V. Addition of milk prevents vascular protective effects of tea. Eur Heart J 2007; 28:219-223. 